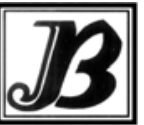

J. bio-sci. 17: 57-62, 2009

ISSN 1023-8654

http://www.banglajol.info/index.php/JBS/index

\title{
OVICIDAL ACTIVITY OF ESSENTIAL OILS AGAINST RED FLOUR BEETLE, TRIBOUUM CASTANEUM(HERBST) (COLEOPTERA: TENEBRIONIDAE)
}

\author{
Mina Mondal, M Khalequzzaman* \\ Department of Zoology, University of Rajshahi, Rajshahi 6205, Bangladesh
}

\begin{abstract}
Context: The essential oils are being tried as potential candidates for pest and disease management. Several essential oils of botanical origin have been reported for their repellant, toxic and developmental inhibitory activities. The ovicidal effect of essential oil is probably the major factor in the suppression of the development of adults from treated eggs.

Objectives: To investigate the ovicidal effect of vapours of five essential oils viz., cardamom (Elletaria cardamomum L.), cinnamon (Cinnamomum zeylanicum Blume), clove (Sygium aromaticum L. Merrill. et. Perry), Eucalyptus spp. and neem (Azadirectica indica A. juss) against the eggs of red flour beetle, Tribolium castaneum (Herbst).

Materials and Methods: Ten eggs ( $24 \mathrm{~h}$ old) of $T$. castaneum were placed in each petridish with wheat flour as food medium and without flour medium and then the petridish were kept inside $650 \mathrm{ml}$ jars with screwed lids. Aliquots of $0.5 \mathrm{ml}$ of each dose of essential oils were applied on filter paper attached to the lower side of the lids. The exposure periods were $24,48,72$ and $96 \mathrm{~h}$, respectively. After treatment periods, petridishes were taken out of the jars and the final mortality counts were made after 11 days. Mortality data were subjected to probit analysis.

Results: The oils had high-fumigant activity against eggs and toxicity progressively increased with increase in exposure time and concentration. At the highest concentration of $5.769 \mathrm{mg} / \mathrm{l}$ air and exposure period of $24 \mathrm{~h}$, cinnamon oil achieved $100 \%$ mortality in flour and without flour media. The vapours of essential oils from cardamom and clove resulted in 100\% mortality of the eggs. Neem oil achieved mortalities as high as 51.66 and $50 \%$ mortality at the highest concentration and exposure period in with-flour and without flour medium respectively. At a concentration of $5.769 \mathrm{mg} / \mathrm{I}$ air cardamom oil, the LT90 values were 50.80 and $62.78 \mathrm{~h}$ for with-flour and without flour medium respectively.

Conclusion: The essential oils of cinnamon and clove, proved to be promising as control agents against stored-product insects, especially $T$. castaneum.
\end{abstract}

Key words: Essential oil, Fumigant toxicity, Ovicidal activity, Tribolium castaneum

\section{Introduction}

World over, pests (especially weeds, pathogens and insects) are the largest competitor of agricultural crops and severely reduce the crop production in the range of $25-50 \%$ (Oerke 2006). To protect agricultural crops enormous amount of synthetic pesticides are used. As per Agrow (2007) report, the total value of world's agrochemical market was between US\$31-35 billion and among the products herbicides accounted for 48 $\%$ followed by insecticides (25\%) and fungicides $(22 \%)$.

However, the excessive use of synthetic pesticides in the croplands, urban environment, and water bodies to get rid of noxious pests has resulted in an increased risk of pesticide resistance, enhanced pest resurgence and development of resistance/ cross-resistance, toxicological implications to human health and increased environmental pollution. In fact, combating of environmental pollution and its ill-effects on the life and life

•Corresponding author: kzaman@ru.ac.bd 
support systems is one of the most serious challenges before the present day world. Efforts are thus being made world over to replace these synthetic chemicals with alternatives, which are safer and do not cause any toxicological effects on the environment. The natural pest and disease control either directly or indirectly using natural plant products/botanicals, including essential oils, holds a good promise (Isman 2000, 2006, Bakkali et al. 2008).

Aromatic plants and their essential oils have been used since antiquity in flavor and fragrances, as condiment or spice, in medicines, as antimicrobial / insecticidal agents, and to repel insect or protect stored products (Dorman and Deans 2000, Isman and Machial 2006, Bakkali et al. 2008). These constitute effective alternatives to synthetic pesticides without producing adverse effects on the environment (Isman 2000, Isman and Machial 2006). However, the attempts to characterize their pest control activity under in vitro conditions started in 1900s (Dorman and Deans 2000). Moreover, the interest in essential oils has regained momentum during the last decade, primarily due to their fumigant and contact insecticidal activities and the less stringent regulatory approval mechanisms for their exploration due to long history of use (Isman 2006).

Of late, the essential oils are being tried as potential candidates for pest and disease management (Isman 2000, Pawar and Thaker 2006, Abad et al. 2007). Essential oils may act as fumigants (Negahban et al. 2006, 2007, Ogendo et al. 2008, Sahaf et al. 2008), contact insecticides (García et al. 2007), repellents (Prajapati et al. 2005, García et al. 2007, Ogendo et al. 2008, Cosimi et al. 2009, Nerio et al. 2009), antifeedants (Harwood et al. 1990, Han et al. 2006) and may affect some biological parameters such as ovicidal activity, growth rate, life span and reproduction inhibition (Isman 2000, Weaver and Subramanyam 2000, Prajapati et al. 2005).

Therefore, in order to better understand the response of the egg stage to essential oils and especially their vapours or their constituents, there is a need for systematic investigations of the effect of different essential oil concentrations and exposure periods on stored-product insects. The present study was undertaken to investigate the effect of vapours of five essential oils against the eggs of red flour beetle, Tribolium castaneum (Herbst)

\section{Materials and Methods}

Collection of eggs: The wheat flour was used as the food medium for $T$. castaueum culture. A standard mixture of whole-wheat flour with powdered dry yeast in a ratio of 19:1 (Khalequzzaman et al. 1994) was used as food medium throughout the experimental period. Form culture of the red flour beetle, about 500 beetles was placed in $500 \mathrm{ml}$ beaker containing food medium of whole-wheat mill flour. The beaker was covered with a piece of cloth and kept in an incubator at $28 \pm 1^{\circ} \mathrm{C}$. After $24 \mathrm{~h}$ interval the eggs were collected by sieving the food medium by two sieves of 500 and $250 \mu \mathrm{m}$ aperture separating the adults and eggs respectively.

Essential oils: Five essential oils; cardamom (Elletaria cardamomum L.), cinnamon (Cinnamomum zeylanicum Blume), clove (Sygium aromaticum L. Merrill et. Perry), Eucalyptus spp. and neem (Azadirectica indica A. Juss) were used. Those essential oils were procured from the pharmacy as of $90 \%$ purity and were further purified in the rotary evaporator in the Crop Protection and Toxicology Laboratory, Department of Zoology, Rajshahi University.

Ovicidal activity of essential oils: The eggs were exposed to essential oils on $6 \mathrm{~cm}$ petridish. Ten eggs $(24 \mathrm{~h}$ old) were placed in each petridish with flour as food medium and without flour as no food medium and then the petridish were kept in $650 \mathrm{ml}$ jars with screwed lids. Aliquots of $0.5 \mathrm{ml}$ of each dose of essential oil was applied on filter paper (Whatman No. 1), cut into $6 \mathrm{~cm}$ diameter, and were attached to the lower side of the lid of the jar. After evaporation of the solvent in about two minutes, the lids were closed tightly with the jars. The exposure periods were $24,48,72$ and $96 \mathrm{~h}$, respectively. After exposure, petridishes were taken out of the jars and kept in the incubator at at $28 \pm 1^{\circ} \mathrm{C}$. The final mortality counts were made after 11 days with the help of a stereomicroscope. Unhatched eggs were counted as dead. 
Analysis of the data: Percentage mortality was calculated and data were corrected for natural mortality in controls using the Abbott (1925) formula. The corrected mortality were then subjected to probit analysis to estimate LT 50 and LT99 values (Sokal and Rohlf 1973). To demonstrate the difference between flour and without-flour media t-test were done. Analysis of variance (ANOVA) was used to determine the effect of essential oil concentrations on ovicidal activity. Following a significant ANOVA, differences amongst means were established using Least Significant Difference (LSD) test at 1\% level.

\section{Results}

Essential oil vapours showed variable toxicity to egg of $T$. castaneum. There is no significant difference between flour and without flour media (t-values were insignificant) in all oils except neem oil $(P<0.05)$ at 24 $\mathrm{h}$ treatment.. However, only the cinnamon oil achieved a mortality of $100 \%$ to all exposure periods against the eggs of $T$. castaneum both in flour and without flour media. Cardamom oil achieved $100 \%$ mortality at the highest concentration and exposure period of $96 \mathrm{~h}$ in both media. Clove oil showed $100 \%$ mortality at the highest concentration in without flour medium to $24 \mathrm{~h}$ exposure period, whereas, $48.33 \%$ mortality in flour medium. Eucalyptus oil showed 25.00 and $10.00 \%$ egg mortality in without flour and flour media respectively after $24 \mathrm{~h}$ exposure. Neem oil was less toxic and achieved 51.66 and $50.00 \%$ mortality at the highest concentration at $96 \mathrm{~h}$ exposure period in flour and without flour media respectively (Table 1).

Table I. Mean percent of egg mortality of Tribolium castaneum in different essential oils treated in different hours of time.

\begin{tabular}{|c|c|c|c|c|c|c|c|c|}
\hline \multirow{2}{*}{$\begin{array}{l}\text { Essential } \\
\text { oil } \\
\left(\mathrm{mg}^{-1} \text { air }\right)\end{array}$} & \multicolumn{2}{|c|}{$\%$ mortality after $24 \mathrm{~h}$} & \multicolumn{2}{|c|}{$\%$ mortality after $48 \mathrm{~h}$} & \multicolumn{2}{|c|}{$\%$ mortality after $72 \mathrm{~h}$} & \multicolumn{2}{|c|}{$\%$ mortality after $96 \mathrm{~h}$} \\
\hline & $\begin{array}{l}\text { without } \\
\text { flour }\end{array}$ & with flour & $\begin{array}{l}\text { without } \\
\text { flour }\end{array}$ & with flour & $\begin{array}{l}\text { without } \\
\text { flour }\end{array}$ & with flour & $\begin{array}{l}\text { without } \\
\text { flour }\end{array}$ & with flour \\
\hline $\begin{array}{c}5.769 \\
2.884 \\
1.442 \\
0.721 \\
\text { Control }\end{array}$ & $\begin{array}{c}100 \\
100 \\
100 \\
60.00 \\
00 \\
\mathrm{df}=5, \mathrm{t}\end{array}$ & $\begin{array}{c}100 \\
100 \\
100 \\
35.00 \\
00 \\
27, \text { NS } \\
\end{array}$ & $\begin{array}{l}100 \\
100 \\
100 \\
100 \\
00\end{array}$ & $\begin{array}{l}100 \\
100 \\
100 \\
100 \\
00\end{array}$ & $\begin{array}{l}\text { on } \\
100 \\
100 \\
100 \\
100 \\
00\end{array}$ & $\begin{array}{c}100 \\
100 \\
100 \\
100 \\
00\end{array}$ & $\begin{array}{c}100 \\
100 \\
100 \\
100 \\
00\end{array}$ & $\begin{array}{c}100 \\
100 \\
100 \\
100 \\
00\end{array}$ \\
\hline $\begin{array}{c}5.769 \\
2.884 \\
1.442 \\
0.721 \\
\text { Control }\end{array}$ & $\begin{array}{c}56.66 \\
40.00 \\
16.66 \\
11.66 \\
00 \\
\mathrm{df}=6,\end{array}$ & $\begin{array}{c}55.00 \\
30.00 \\
11.66 \\
3.33 \\
00 \\
0, \text { NS }\end{array}$ & $\begin{array}{c}83.33 \\
68.33 \\
30.00 \\
18.33 \\
00 \\
d f=6,\end{array}$ & $\begin{array}{c}\text { Ca } \\
88.33 \\
41.66 \\
20.00 \\
16.66 \\
00 \\
69, \text { NS }\end{array}$ & $\begin{array}{c}\text { om } \\
91.66 \\
70.00 \\
46.66 \\
28.33 \\
00 \\
d f=6,\end{array}$ & $\begin{array}{c}96.66 \\
66.66 \\
35.00 \\
18.33 \\
00 \\
25, \text { NS }\end{array}$ & $\begin{array}{c}100 \\
100 \\
46.66 \\
31.66 \\
00 \\
\mathrm{df}=6,\end{array}$ & $\begin{array}{c}100 \\
70.00 \\
58.33 \\
18.33 \\
00 \\
22, \text { NS }\end{array}$ \\
\hline $\begin{array}{c}5.769 \\
2.884 \\
1.442 \\
0.721 \\
\text { Control }\end{array}$ & $\begin{array}{c}100 \\
41.66 \\
28.33 \\
10.00 \\
00 \\
\mathrm{df}=4\end{array}$ & $\begin{array}{r}48.33 \\
28.33 \\
25.00 \\
16.66 \\
00 \\
49, \text { NS }\end{array}$ & $\begin{array}{c}100 \\
91.66 \\
60.00 \\
26.66 \\
00 \\
d f=5\end{array}$ & $\begin{array}{r}70.00 \\
33.33 \\
26.66 \\
25.00 \\
00 \\
59, \text { NS }\end{array}$ & $\begin{array}{c}100 \\
91.66 \\
73.33 \\
48.33 \\
00 \\
d f=6\end{array}$ & $\begin{array}{c}83.33 \\
46.66 \\
33.33 \\
28.33 \\
00 \\
30, \text { NS }\end{array}$ & $\begin{array}{c}100 \\
96.66 \\
80.00 \\
76.66 \\
00 \\
\mathrm{df}=4,\end{array}$ & $\begin{array}{r}93.33 \\
53.33 \\
43.33 \\
35.00 \\
00 \\
62, \text { NS }\end{array}$ \\
\hline $\begin{array}{c}5.769 \\
2.884 \\
1.442 \\
0.721 \\
\text { Control }\end{array}$ & $\begin{array}{c}25.00 \\
13.33 \\
8.33 \\
3.33 \\
00 \\
\mathrm{df}=6, \mathrm{t}\end{array}$ & $\begin{array}{c}10.00 \\
26.66 \\
5.00 \\
3.33 \\
00 \\
76, \text { NS }\end{array}$ & $\begin{array}{c}70.00 \\
55.00 \\
33.33 \\
13.33 \\
00 \\
\mathrm{df}=6,\end{array}$ & $\begin{array}{c}\text { EL } \\
65.00 \\
53.33 \\
21.66 \\
6.66 \\
00 \\
40, \text { NS }\end{array}$ & $\begin{array}{l}\text { tus } \\
85.00 \\
71.66 \\
41.66 \\
23.33 \\
00 \\
\text { df }=6 \text {, }\end{array}$ & $\begin{array}{c}80.00 \\
58.33 \\
28.33 \\
18.33 \\
00 \\
60, \text { NS }\end{array}$ & $\begin{array}{c}96.66 \\
83.33 \\
51.66 \\
31.66 \\
00 \\
\mathrm{df}=6,\end{array}$ & $\begin{array}{r}90.00 \\
68.33 \\
46.66 \\
20.00 \\
00 \\
55, \text { NS }\end{array}$ \\
\hline $\begin{array}{c}5.769 \\
2.884 \\
1.442 \\
0.721 \\
\text { Control }\end{array}$ & $\begin{array}{c}23.33 \\
18.33 \\
11.66 \\
5.00 \\
00 \\
d f=3, t=?\end{array}$ & $\begin{array}{c}00 \\
00 \\
00 \\
00 \\
00 \\
p<0.05\end{array}$ & $\begin{array}{c}31.66 \\
25.00 \\
18.33 \\
6.66 \\
00 \\
d f=5\end{array}$ & $\begin{array}{r}20.00 \\
15.00 \\
6.66 \\
3.33 \\
00 \\
98, \text { NS }\end{array}$ & $\begin{array}{c}38.33 \\
31.66 \\
25.00 \\
11.66 \\
00 \\
d f=6,\end{array}$ & $\begin{array}{r}40.00 \\
21.66 \\
13.33 \\
5.00 \\
00 \\
08, \text { NS }\end{array}$ & $\begin{array}{c}50.00 \\
38.33 \\
23.33 \\
13.33 \\
00 \\
d f=5\end{array}$ & $\begin{array}{c}51.66 \\
46.66 \\
18.33 \\
5.00 \\
00 \\
6, \text { NS }\end{array}$ \\
\hline
\end{tabular}


All the doses caused $100 \%$ mortality of eggs of $T$. castaneum in cinnamon oil, so the lethal time could not be calculated. At the highest concentration level of cardamom oil, the time required for $50 \%$ (LT50) and $90 \%$ (LT90) kill of eggs were 22.49 and $50.80 \mathrm{~h}$ in flour medium and 20.73 and $62.78 \mathrm{~h}$ in without flour medium, respectively. For clove oil the $\mathrm{LT}_{50}$ was $26.00 \mathrm{~h}$ and $\mathrm{LT}_{90}$ was $96.02 \mathrm{~h}$ at the highest concentration level in flour medium, but without flour medium, $100 \%$ mortality was occurred. The $\mathrm{LT}_{50}$ and $\mathrm{LT} \mathrm{T}_{90}$ were estimated as 44.42 and $90.61 \mathrm{~h}$ in flour medium and 35.90 and $76.73 \mathrm{~h}$ in without flour medium at the highest concentration level of eucalyptus oil. However, the $L T_{50}$ and $L T_{90}$ of neem oil at the same dose were 87.93 and $191.98 \mathrm{~h}$ for flour medium and 114.41 and $1425.43 \mathrm{~h}$ for without flour medium, respectively (Table 2).

Table 2. $\mathrm{LT}_{50}(\mathrm{~h})$ and $\mathrm{LT} \mathrm{T}_{90}(\mathrm{~h})$ of different concentrations of essential oils against the mortality of eggs of $T$. castaneum.

\begin{tabular}{|c|c|c|c|c|c|c|c|c|}
\hline \multirow{2}{*}{ Dose $\left(\mathrm{mg}^{-1}\right)$} & \multicolumn{2}{|c|}{ Cardamom } & \multicolumn{2}{|c|}{ Clove } & \multicolumn{2}{|c|}{ Eucalyptus } & \multicolumn{2}{|c|}{ Neem } \\
\hline & $\mathrm{LT}_{50}$ & $\mathrm{LT}_{90}$ & $\mathrm{LT}_{50}$ & $\mathrm{LT}_{90}$ & $\mathrm{LT}_{50}$ & $\mathrm{LT}_{90}$ & $\mathrm{LT}_{50}$ & $\mathrm{LT}_{90}$ \\
\hline \multicolumn{9}{|l|}{ With flour } \\
\hline 5.769 & 22.49 & 50.80 & 26.00 & 96.02 & 44.42 & 90.61 & 87.93 & 191.98 \\
\hline 2.884 & 50.18 & 249.70 & 88.47 & 1174.56 & 50.58 & 278.65 & 102.88 & 225.05 \\
\hline 1.442 & 93.42 & 341.15 & 219.22 & 9546.90 & 108.69 & 363.02 & 202.51 & 631.35 \\
\hline 0.721 & 377.47 & 3444.6 & 286.38 & 7777.68 & 248.61 & 1180.1 & 771.33 & 4430.67 \\
\hline \multicolumn{9}{|l|}{ Without flour } \\
\hline 5.769 & 20.73 & 62.78 & * & * & 35.90 & 76.73 & 114.41 & 1425.4 \\
\hline 2.884 & 31.19 & 179.23 & 25.60 & 58.32 & 48.49 & 116.68 & 209.80 & 3969.3 \\
\hline 1.442 & 97.42 & 629.45 & 40.80 & 145.73 & 86.44 & 317.19 & 643.16 & 24414.9 \\
\hline 0.721 & 239.45 & 2805.97 & 67.60 & 166.44 & 154.21 & 561.13 & 1486.9 & 34838.2 \\
\hline
\end{tabular}

\section{Discussion}

Ovicidal activity is only apparent when the target system (the nervous system in this case), begins to develop (Michaelides and Wright 1997). Alternatively, changes in the permeability of the chorion and/ or vitelline membrane may occur during embryogenesis and may facilitate the diffusion of vapours into older eggs so that vital physiological and biochemical processes are affected (Gurusubramanian and Krishna 1996). These factors have been considered to play a dominant role in the susceptibility of eggs of many insect species to different ovicides including organophosphates, carbamates and dinitrophenols (Smith and Salkeld 1966, Michaelides and Wright 1997).

Previously for the management of economic loss caused by T. castaneum, several essential oils of botanical origin have been reported for their repellant, toxic and developmental inhibitory activities. Essential oils of Anethum sowa (Tripathi et al. 2000a), Artemisia annua (Tripathi et al. 2000b), Lippia alba (Verma et al. 2000) and Elletaria cardomum (Huang et al. 2000) have been reported for their repellant and toxic behavior against $T$. castaneum. Although cardamom oil did not prevent the oviposition but it was ovicidal to the eggs of $T$. castaneum. In addition, it also prevented the eggs treated with the oil from developing to the adult stage. Hence, the ovicidal effect of cardamom oil was probably the major factor in the suppression of the development of adults from treated eggs (Huang et al. 2000). An ovicidal effect on T. castaneum was also found in the essential oils of garlic (Ho et al. 1996) and nutmeg (Huang et al. 1997). Ho et al. (1995) investigated that hexane extracts of star anise were ovicidal to eggs of $T$. castaneum. Moreover, it is well known that rosemary oil has ovicidal activity against other insects such as T. confusum du Val and Ephestia kuehniella Zeller (Tunç et al. 2000).

Comparison of the results with earlier investigations (Saraç and Tunç 1995) demonstrates that responses of the egg stage and active stages of stored-product insects to essential oils are different. Eggs of $T$. confusum were more tolerant towards anise oil than the adults (Tunç et al. 2000). However, the eggs of E. kuehniella 
were less tolerant towards the essential oil than the last larval instars at comparable concentrations and exposure periods (Saraç and Tunç 1995). Compared with the investigation of Shaaya et al. (1993), the results demonstrate a much lower toxicity of the essential oil of oregano against eggs of $T$. confusum and $E$. kuehniella (Tunç et al. 2000). The exposure to vapours of essential oils from anise and cumin resulted in $100 \%$ mortality of the eggs of $T$. confusum. Oregano achieved mortalities as high as $77 \%$ and $8 \%$ in $T$. confusum and E. kuehniella, respectively. At a concentration of $98.5 \mathrm{ml}$ anise essential oil// air, the LT99 values were $60.9 \mathrm{~h}$ and $253.0 \mathrm{~h}$ for $E$. kuehniella and $T$. confusum, respectively. For the same concentration of the essential oil of cumin, the LT99 value for $E$. kuehniella was $127.0 \mathrm{~h}$. As the essential oils from other plants investigated were less active their estimated LT99 values were too far beyond the tested exposure range to be reliable (Tunç et al. 2000).

\section{Conclusion}

Our results and those reported earlier clearly indicate variations in the activity of essential oils regarding the stage of the insect, the species of the insect and the plant origin of the essential oil. Not all the essential oils tested showed satisfactory activity, but the essential oils of cinnamon, and also clove, proved to be promising as control agents against stored-product insects, especially $T$. castaneum.

\section{Reference}

Abad MJ, Ansuategui M, Bermejo P. 2007. Active antifungal substances from natural sources. ARKIVOC 2007 (vii), 116-145.

Abbott WS. 1925. A method of computing the effectiveness of an insecticide. J Econ Entomol 18, 265-267.

Agrow 2007. Agrow's Top 20: 2007 Edition' report to help plan your strategy and outlook for 2008 and analyse detailed profiles of the 20 largest agrochemical companies". Informa Health Care, London, http://findarticles.com/p/articles/mi_m0EIN/is_2008_Jan_18/ai_n24236510/.

Bakkali F, Averbeck S, Averbeck D, Idaomar M. 2008. Biological effects of essential oils-a review. Food Chem Toxicol 46, 446-475. doi:10.1016/j.fct.2007.09.106

Cosimi S, Rossi E, Cioni PL, Canale A. 2009. Bioactivity and qualitative analysis of some essential oils from Mediterranean plants against stored-product pests: Evaluation of repellency against Sitophilus zeamais Motschulsky, Cryptolestes ferrugineus (Stephens) and Tenebrio molitor (L.). J Stored Prod Res 45, 125-132.

Dorman HJD, Deans SG. 2000. Antimicrobial agents from plants: antibacterial activity of plant volatile oils. J Appl Microbiol 88, 308-316. doi:10.1046/j.1365-2672.2000.00969.x

García M, Gonzalez-Coloma A, Donadel OJ, Ardanaz CE, Tonn CE, Sosa ME. 2007. Insecticidal effects of Flourensia oolepis Blake (Asteraceae) essential oil. Biochem. Syst Ecol 35, 181-187. doi:10.1016/j.bse.2006.10.009

Gurusubramanian G, Krishna SS. 1996. The effects of exposing eggs of four cotton insects pests to volatiles of Allium sativum (Liliaceae). Bull Entomol Res 86, 29-31. doi:10.1017/S0007485300052160

Han MK, Kim SI, Ahn YJ. 2006. Insecticidal and antifeedant activities of medicinal plant extracts against Attagenus unicolor japonicus (Coleoptera: Dermestidae). J Stored Prod Res 42, 15-22. doi:10.1016/j.jspr.2004.11.002

Harwood HS, Moldenke FA, Berry ER. 1990. Toxicity of monoterpenes to the variegated cutworm (Lepidoptera: Noctuidae). J Econ Entomol 83, 1761-1767. doi:10.1016/0925-5214(95)00015-X

Ho SH, Ma Y, Goh MP, Sim KY. 1995. Star anise, Illicium verum Hook f. as a potential grain protectant against Tribolium castaneum (Herbst) and Sitophilus zeamais Motsch. Postharvest Biol Technol 6, 341-347.

Ho SH, Koh L, Ma Y, Huang Y, Sim KY. 1996. The oil of garlic, Allium sativum L. (Amaryllidaceae), as a potential grain protectant against Tribolium castaneum (Herbst) and Sitophilus zeamais Motsch. Postharvest Biol Technol 9, 41-48.

Huang Y, Tan JMWL, Kini RM, Ho SH. 1997. Toxic and antifeedant action of nutmeg oil against Tribolium castaneum (Herbst) and Sitophilus zeamais Motsch. J Stored Prod Res 33, 289-298. doi:10.1016/S0022-474X(97)00009-X 
Huang Y, Lam SL, Ho SH. 2000. Bioactivities of essential oil from Elletaria cardamomum L. Maton, to Sitophilus zeamais Motsch and Tribolium castaneum (Herbst). J Stored Prod Res 36, 107-117. doi:10.1016/S0022-474X(99)00040-5

Isman MB. 2000. Plant essential oils for pest and disease management. Crop Prot 19, 603-608.

Isman MB. 2006. Botanical insecticides, deterrents, and repellents in modern agriculture and an increasingly regulated world. Annu Rev Entomol 51, 45-66. doi:10.1146/annurev.ento.51.110104.151146

Isman MB, Machial CM. 2006 Pesticides based on plant essential oils: from traditional practice to commercialization. In: Naturally Occurring Bioactive Compounds. Advances in Phytomedicine (Eds. M Rai, MC Carpinella) Elsevier, New York, pp. 29-44. doi:10.1016/S1572-557X(06)03002-9

Khalequzzaman M, Khaton M, Talukdar D. 1994. Growth of Tribolium confusum Duv. on wheat flour with various yeast lavels. Int Pest Control 36, 128-130.

Michaelides PK, Wright DJ. 1997. Activity of soil insecticides on eggs of Diabrotica undecimpunctata howardi: effects on embryological development and influence of egg age. Pestic Sci 49, 1-8.

Negahban M, Moharramipour S, Sefidkon F. 2006. Insecticidal activity and chemical composition of Artemisia sieberi Besser essential oil from Karaj, Iran. J Asia-Pacific Entomol 9, 61-66. doi:10.1016/S1226-8615(08)60276-9

Negahban M, Moharramipour S, Sefidkon F. 2007. Fumigant toxicity of essential oil from Artemisia sieberi Besser against three stored-product insects. J Stored Prod Res 43, 123-128. doi:10.1016/j.jspr.2006.02.002

Nerio LS, Olivero-Verbel J, Stashenko EE. 2009. Repellent activity of essential oils from seven aromatic plants grown in Colombia against Sitophilus zeamais Motschulsky (Coleoptera). J Stored Prod Res 45, 212-214.

Oerke EC. 2006. Crop losses to pests. J Agric Sci 144, 31-43. doi:10.1017/S0021859605005708

Ogendo JO, Kostyukovsky M, Ravid U, Matasyoh JC, Deng AL, Omolo EO, Kariuki ST, Shaaya E. 2008. Bioactivity of Ocimum gratissimum L. oil and two of its constituents against five insect pests attacking stored food products. J Stored Prod Res 44, 328-334. doi:10.1016/j.jspr.2008.02.009

Pawar VC, Thaker VS. 2006. In vitro efficacy of 75 essential oils against Aspergillus niger. Mycoses 49, 316-323.

Prajapati V, Tripathi AK, Aggarwal KK, Khanuja SPS. 2005. Insecticidal, repellent and oviposition-deterrent activity of selected essential oils against Anopheles stephensi, Aedes aegypti and Culex quinquefasciatus. Bioresource Technol 96, 1749-1757. doi:10.1016/j.biortech.2005.01.007

Sahaf BZ, Moharramipour S, Meshkatalsadat MH. 2008. Fumigant toxicity of essential oil from Vitex pseudo-negundo against Tribolium castaneum (Herbst) and Sitophilus oryzae (L.). J Asia-Pacific Entomol 11, 175-179.

Saraç A, Tunç I. 1995. Toxicity and of essential oils to stored product insects. J Plant Dis Protect 102, 69-74.

Shaaya E, Ravid U, Paster N, Kostjukovski M, Menasherov M, Plotkin S. 1993. Essential oils and their components as active fumigants against several species of stored product insects and fungi. Acta Horticulturae 344, 131-137.

Smith EH, Salkeld HE. 1966. The use and action of ovicides. Annu Rev Entomol 11, 331-368.

Sokal RR, Rohlf FJ. 1973. Introduction to Biostatistics. Freeman and Company, San Francisco.

Tripathi AK, Prajapati V, Aggrawal KK, Khanuja SPS, Kumar S. 2000a. Toxicity towards Tribolium castaneum in the fraction of essential oil of Anethum sowa seeds. J Med Arom Plant Sci 22, 146-150.

Tripathi AK, Prajapati V, Aggrawal KK, Khanuja SPS, Kumar S. 2000b. Repellency and toxicity of oil from Artemisia annua to certain stored product beetles. J Econ Entomol 93, 43-47. doi:10.1603/0022-0493-93.1.43

Tunç Í, Berger BM, Erler F, Dağli F. 2000. Ovicidal activity of essential oils from five plants against two stored product insects. J Stored Prod Res 36, 161-168. doi:10.1016/S0022-474X(99)00036-3

Verma N, Tripathi AK, Prajapati V, Bahl JR, Bansal RP, Khanuja SPS, Kumar S. 2000. Toxicity of essential oil from Lippia alba towards stored grain insects. J Med Arom Plant Sci 22, 117-119.

Weaver DK, Subramanyam B. 2000. Botanicals. In: Alternatives to Pesticides in Stored-Product IPM (eds. B Subramanyam, DW Hagstrum). Kluwer Academic Publishers, Massachusetts, USA. pp. 303-320. 